\title{
CHANGING INSTITUTIONAL ARRANGEMENTS OF INTERNATIONAL INVESTMENT DISPUTE RESOlUTION IN A GLOBAL ORDER: THREE DIFFERENT APPROACHES
}

\author{
Michel Roberto OliveIRA De SOUZA ${ }^{\dagger}$
}

\begin{abstract}
This article explores three different approaches in changing the international investment dispute resolution institutional arrangement models. To do this, it first analyses the hegemonic Bilateral Investment Treaties' system of investor-State arbitration. Then the article focuses on critics related to the procedure, regarding jurisdictional issues. Thirdly, it presents three different approaches to change institutional arrangements in the investment dispute resolution system, as the European, the U.S. and the Brazilian approaches.
\end{abstract}

KEYWORDS: International Investment Dispute Settlement; Bilateral Investment Treaties; Institutional Arrangement.

RESUMO: $\mathrm{O}$ artigo explora três diferentes abordagens na mudança do sistema de disputas internacionais relacionadas ao investimento. Para fazer isso, primeiro analisa-se o modelo hegemônico caracterizado pela arbitragem entre investidor e Estado previstas em tratados bilaterais de investimento (BIT). Na sequência, o artigo foca nas críticas relacionadas ao procedimento da arbitragem em BITs, principalmente em questões jurisdicionais. Por fim, o artigo analisa três abordagens propostas hodiernamente ao se modificar o sistema de disputas de investimentos

\footnotetext{
† SJD Student at Universidade de São Paulo with CAPES/CNPq scholarship. LLB at Universidade Estadual de Maringá. LLM at Universidade de São Paulo and at International University College of Turin, Italy. I would like to thank all the IUC professors and staff for the support with this research, mainly professors Ugo Mattei, Giuseppe Mastruzzo and Francesco Costamagna.
} 
internacionais, como as abordagens europeia, estadunidense e brasileira.

PAlaVRAS-ChAVe: Sistema de Disputas de Investimentos Internacionais; Tratados Internacionais de Investimento; Arranjos Institucionais.

\section{TABLE OF CONTENT:}

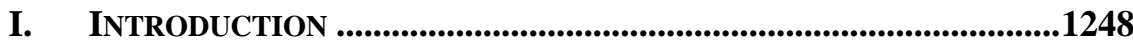

II. INTERNATIONAL INVESTMENT DISPUTE SETTLEMENT: ...................... THE HEGEMONIC INSTITUTIONAL ARRANGEMENT MODEL.............1250

1. The International Investment Law....................................1250

2. The affected and interested parties involved in the conflict and the dispute's issues...............................................................1251

3. Investor-State disputes and provisions on dispute settlement ....................................................................1253

4. Arbitration in International Investment Dispute Settlement.....................1256

III. FAILURES (OR CONCERNS) OF ARBITRATION SETTLEMENT MODEL .........................................1258

IV. OVERCOMING THE FAILURES? ...................................................1262

1. European approach ..............................................................1264

1.1. Comprehensive Economic Trade Agreement (CETA)1264

1.2. Transatlantic Trade and Investment Partnership (TTIP): the International Investment Court.............................. 1266

2. USA approach: the Trans-Pacific Partnership (TPP) Agreement..............1269

3. Brazilian approach: agreements on cooperation and facilitation of investments1271

V. ONE STEP BACK:

UNDERSTAND THE CHALLENGES TO OVERCOME THEM ...................1274

VI. CONCLUSION ...................................................................................1276

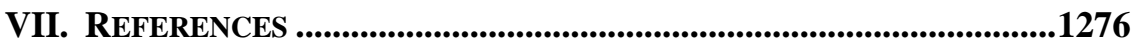




\section{SUMÁRIO:}

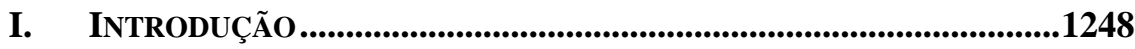

II. SISTEMA DE DISPUTAS DE INVESTIMENTOS INTERNACIONAIS:

O MODELO DE ARRANJO INSTITUCIONAL HEGEMÔNICO................1250

1. O Direito do Investimento Internacional ...........................1250

2. As partes afetadas e interessadas no conflito e as questões da disputa...............................................................1251

3. Disputas e provisões do Estado-Investidor na resolução de conflitos......................................................1253

4. Arbitragem na Resolução de Disputas em Investimento Internacional .........................................1256

III. FALHAS (OU PREOCUPAÇÕES)

DO MODELO DE RESOLUÇÃO ARBITRAL ............................................1258

IV. SUPERANDO AS FALHAS? ...................................................................1262

1. Perspectiva Europeia.................................................................1264

1.1. Acordo Econômico e Comercial Global (CETA).......1264

1.2. Parceria Transatlântica de Comércio e Investimento

(TTIP): a Corte de Investimento Internacional .........1266

2. Perspectiva dos EUA:

o acordo de Parceria Transpacífico (TPP) ..........................1269

3. Perspectiva brasileira: acordos de cooperação e facilitação de investimentos .....1271

V. UM PASSO PARA TRÁS:

COMPREENDER OS DESAFIOS PARA SUPERÁ-LOS............................1274

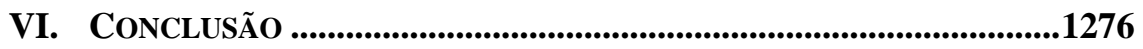

VII. REFERÊNCIAS.................................................................................................1276 


\section{INTRODUCTION}

This essay investigates the international investment dispute resolution institutional arrangement models. The clashes of interests between the host State and the foreign investor are mostly solved by arbitration, since that is the most common dispute resolution method adopted by Bilateral Investment Treaties (BIT). Van Harten classifies the international investor-state arbitration as a "type of public law adjudication", because it is "established by a sovereign act of the state and because it is used to resolve regulatory disputes". ${ }^{1}$ The growth of investor-state arbitration disputes shows that there is always a tension between the investors and host States' interests.

Some scholars say that international investment law is related to the protection of foreign investment "against interference by the host State". ${ }^{2}$ The aim of foreign investment law is both to protect foreign investment and to attract and encourage the international private sector to invest in the host State. Setting the applicable law to foreign investment and the protection of procedural rights are some of the conducts the host State takes to promote foreign investment.

The state that signs a BIT aims not only to guarantee the protection to the international investor who will invest in the host state, but also to protect their own national investors who will invest in the other contracting state. That happens because the host State gives guarantee of a certain stability and commitment that it will not use its sovereignty to impose losses on the investors.

Between the 1960s and late 1990s, there was a proliferation of BIT's. Sornarajah emphasizes that the "incredible proliferation of bilateral investment treaties" was an evidence of the economic liberalism triumph at the end of the last millennium. ${ }^{3}$ This change affected international law on foreign investment.

The critics of investor-State dispute resolution adopts two different standpoints, one substantive, related to substantive law, and other related to the procedure, regarding jurisdictional issues. One example of what

${ }^{1}$ Gus Van Harten, The Public-Private Distinction in the International Arbitration of Individual Claims against the State, 56 INTERNATIONAL AND COMPARATIVE CORPORATE LAW QUARTERLY 2, 393 (2007).

2 Christoph Schreuer, Investment, International Protection, in MAX PLANCK ENCYCLOPEDIA OF PUBLIC INTERNATIONAL LAW (Rudiger Wolfrum ed., 2013).

${ }^{3}$ MUTHUCUMARASWAMY SORNARAJAH, THE INTERNATIONAL LAW ON FOREIGN INVESTMENT, 3 (3 ${ }^{\text {RD }}$ ED., 2010). 
can be called substantive standpoint is the tension between the protection of foreign investments and the role that the State has in promoting its own government policies. Such cases raise questions like how and when the host State can use its power of promoting public policies without harming foreign investments already made.

On the other hand, the example of the procedural standpoint critics is related to topics like the judicial sovereignty, how and who will solve the disputes between the parties. These critics considers topics as forum shopping, necessity of exhaustion of local remedies, possible influence of the local community involved in the conflict, access to justice in the host State and sovereignty.

This essay analyzes the critics to the proceedings and the role of the actors involved in this kind of disputes analyzing how the treaties being discussed nowadays set the conflict resolution between foreign investors and host states. For such purpose, the article diagnoses the existing hegemonic investor-state dispute resolution system, focusing on the prevalence of arbitration. Understanding the affected and interested parties involved in the conflict, the disputes' issues and how the disputes are solved will be fundamental in such diagnosis.

For a better organization of the argument, the first chapter has two different topics. First it analyzes the institutional design of arbitration, setting as an example the International Centre for Settlement of Investment Disputes (ICSID), regarding Bilateral Investment Treaties that have the ICSID as the competent institution to administer the investor-State arbitration. Then it analyzes the role of institutional arrangements in dispute resolution and its failures.

The second chapter analyzes the main critics to the arbitration settlement model regarding to its own legitimacy, understanding topics as the state regulatory sovereignty interference and lack of transparency. The chapter aims to understand some characteristics of the investor-state conflict, thinking about the priorities of both the investor and the States. Lastly, the third chapter focuses on how dispute resolution between investors and host states are set in recent multilateral treaties negotiations. That part of this article aims to understand the role that is being designed to foreign investment disputes in the treaties being discussed in the world, as Comprehensive Economic and Trade Agreement (CETA), Trans-Pacific Partnership (TPP) and Transatlantic Trade and Investment Partnership (TTIP), also discussing the recent Brazilian Agreements on Cooperation and Facilitation of Investments (ACFI). In this sense, this article presents three different approaches to reform international investment dispute settlement.

The first approach is the European one, through the analysis of the

3 JOURNAL OF INSTITUTIONAL STUDIES 2 (2017) 
CETA and TTIP. Regarding the North-American approach, TPP is the example analyzed. The last approach is the Brazilian, analyzing how Brazil has changed its policy regarding investment treaties and has signed a different model of treaty that has different provisions to investor-state dispute settlement. The aim of this article is not to advocate for or against such agreement or even other agreements being negotiated. The aim here is to understand the agreement being negotiated and to analyze the specific Investor-State Dispute Settlement (ISDS) topic.

Investor-State dispute resolution has at least three ways to overcome the critics about it. One way is to change the institutional arrangements of the current arbitration system, meaning to change the international arbitration institutions. The second option is to add new elements to the current dispute resolution system, like appellate courts or to put more emphasis on Alternative Dispute Resolution (ADR) mechanisms. The third and last option is to build other institutions, like international courts or other forms of dispute resolution. Although the issue necessarily goes through these fundamental questions related to economic, political and State interests, comparing the main characteristics of different approaches to investor-State dispute resolution could be important not to have a parochial position of which answer is the best for the problem. My position is that all three options have challenges to overcome, and this article tries to summarize such challenges with the emphasis in the role the States have in designing investment dispute resolution in new treaties.

\section{INTERNATIONAL INVESTMENT DISPUTE SETTLEMENT: THE HEGEMONIC INSTITUTIONAL ARRANGEMENT MODEL}

\section{The International Investment Law}

Lately the most important source of international investment law has been the BITs. The Division on Investment and Enterprise of the United Nations Conference on Trade and Development (UNCTAD) says that nowadays there are 2954 BITs, of which 2319 are in force. ${ }^{4}$ These bilateral treaties are "designed to provide guarantees for foreign investors from the respective countries". ${ }^{5}$ Schreuer emphasizes that "[a]lthough many

${ }^{4}$ Available at $<$ http://investmentpolicyhub.unctad.org/>, accessed on Sep. 21, 2016.

${ }^{5}$ Christoph Schreuer, Investment, International Protection, in MAX PLANCK

ENCYClOPEDIA OF PUBLIC INTERNATIONAL LAW, 2 (Rudiger Wolfrum ed., 2013). 
BITs display similarities, they are by no means identical. In some respects, BITs display significant variations" ${ }^{6}{ }^{6}$ Because of these variations, it is difficult to understand all the BITs together, meaning that the interpretation of each BIT should be done on a case by case basis.

But the BITs are not the only source of international investment law. The main sources are: (i) Bilateral Investment Treaties; (ii) Multilateral Treaties, like regional agreements or free trade agreements; ; (iii) case law; (iv) Customary International Law; (v) non-binding Guidelines and Codes of Conduct; and (vi) Investment Contracts.

The multilateral agreement is signed by three or more parties to promote trade and multilateral economic growth. The World Trade Organization (WTO) tried to design the framework of multilateral agreements, but it came to a halt in 2004 because of "the fear of developing countries that a multilateral treaty might unduly narrow their regulatory space" ${ }^{\prime}{ }^{8}$

There are also some regional arrangements that also cover investments and treaties in specialized areas of investment, like the Energy Charter Treaty, signed in 1994. There are ongoing negotiations about some multilateral treaties such as the Comprehensive Economic and Trade Agreement (CETA), a free trade agreement between Canada and the Europe Union with one chapter concerning foreign investment; the TransPacific Partnership (TPP), an agreement between United States, Canada and other 10 countries in the Asia-Pacific Region and the Transatlantic Trade and Investment Partnership (TTIP), a proposal between the United States and Europe Union.

\section{The affected and interested parties involved in the conflict and}

\footnotetext{
${ }^{6}$ Christoph Schreuer, Investment, International Protection, in MAX PLANCK ENCYCLOPEDIA OF PUBLIC INTERNATIONAL LAW, 2 (Rudiger Wolfrum ed., 2013).

7 The agreements "do two things: (1) they subject host countries to a set of international legal rules that they must respect in dealing with foreign investor and their investments and (2) they grant investor the right to bring a claim in international arbitration autonomously and without regard to the wishes of their home country against host country governments that allegedly violate those rules". Jeswald Salacuse, Is There a Better Way? Alternative Methods of Treaty-Based, Investor-State Dispute Resolution, 31 FORDHAM INTERNATIONAL LAW JOURNAL 1, 139 (2007).

${ }^{8}$ Christoph Schreuer, Investment, International Protection, in MAX PLANCK ENCYClOPEDIA OF PUBLIC INTERNATIONAL LAW, 3 (Rudiger Wolfrum ed., 2013).
} 


\section{the dispute's issues}

To solve the cases and conflicts it is necessary to consider the facts and the law involved in the case. In this sense, it is very important to analyze the origin of expectation because it is the source of the expectation (domestic legal framework, law, promises, etc.). The source of the expectation looks to the prudency of the content (if it was reliable); and if it was foreseeable. Also, the behavior of the investor plays a fundamental role in solving the eventual dispute between the State and the foreign investor.

The nature of investor-state disputes is summarized by Salacuse within some characteristics. ${ }^{9}$ The first is that disputes are governed by "public international law in the form of treaties" signed by two or more States. ${ }^{10}$ The second is that the heart of the conflict is generally related to public policy matters, meaning that the dispute decision has "significant implications for the ability of sovereign governments to regulate enterprises within their territories". ${ }^{11}$ Thirdly, as the investments generally "involve public policy issues, investor-state disputes are political in nature and often become highly politicized", with different views and diverse opinions from political actors. The fourth argument concerns the period of investment, since the dispute involves a "long term investment-relationship", frequently a "needed public service". Last, there is a large amount of money involved in the investment.

Taking into account these main characteristics, the key feature of the foreign investment design is "to lay out in advance the risks inherent in such a long term relationship, both from a business perspective and from the legal point of view" ${ }^{12}$ Only after defining these risks that it becomes possible to "identify a business concept and a legal structure that is suitable not only to the implementation of the project in general but also to minimize risks that may arise during the period of investment". ${ }^{13}$

However, this risk identification and business concept is also related

${ }^{9}$ Jeswald Salacuse, Is There a Better Way? Alternative Methods of Treaty-Based, InvestorState Dispute Resolution, 31 FordHAM INTERNATIONAL LAW JOURNAL 1, 143 (2007).

${ }^{10}$ Jeswald Salacuse, Is There a Better Way? Alternative Methods of Treaty-Based, InvestorState Dispute Resolution, 31 FORDHAM INTERNATIONAL LAW JOURNAL 1, 140 (2007).

${ }^{11}$ Jeswald Salacuse, Is There a Better Way? Alternative Methods of Treaty-Based, InvestorState Dispute Resolution, 31 FORDHAM INTERNATIONAL LAW JOURNAL 1, 141 (2007).

12 RUDOLF DOLZER \& CHISTOPH SCHREUER, PRINCIPLES OF INTERNATIONAL INVESTMENT LAW, 4 (2008).

${ }^{13}$ Rudolf DOlZER \& CHISTOPH SCHREUER, PRINCIPLES OF INTERNATIONAL INVESTMENT LAW, 4 (2008). 
to the type of investment that is made. This happens because foreign investment deals with types of business in which the State has a regulatory power to exercise. Examples of investments in public services show that the parties involved in the foreign investment are not only the investor and the State, but also the population affected by the public service.

In this sense, there is a constant clash of interests between different actors like capital-exporting states, capital-importing states, multinational corporations, non-governmental organizations (supporting human rights, environmental and host community interests), host communities, different states' actors (like municipal, provincial states, administrative agencies, federal and regional governments).

\section{Investor-State disputes and provisions on dispute settlement}

There are some forms of settlement of investor-state disputes provided in the main sources of investment law. Salacuse explains four main forms to dispute resolution in general, as (i) negotiation, (ii) mediation, (iii) arbitration, and (iv) adjudication. ${ }^{14}$ According to Salacuse, the disputants increasingly lose control over the resolution of disputes, meaning that with negotiation the disputants have almost all the control over the disputes, and with adjudication, the control is almost all in third parties, the judges. ${ }^{15}$

The probable provision to settle investor-State disputes is to domestic courts settle these disputes. But in this case, investors generally "fear a lack of impartiality", since there is a distrust that domestic courts may impose big losses to the host state and that the host States' regular judges do not know how to deal with international investment law. ${ }^{16}$

Also, related to domestic courts, there is the possibility to determine the requirement to exhaust domestic remedies to access international arbitration or other types of settlement. For example, the ICSID Convention provides that "exhaustion of local administrative or judicial remedies as a condition of its consent to arbitration under this

${ }^{14}$ Jeswald Salacuse, Is There a Better Way? Alternative Methods of Treaty-Based, InvestorState Dispute Resolution, 31 FORDHAM INTERNATIONAL LAW JOURNAL 1, 154-156 (2007).

${ }^{15} \mathrm{Cf}$. Jeswald Salacuse, Is There a Better Way? Alternative Methods of Treaty-Based, Investor-State Dispute Resolution, 31 FORDHAM INTERNATIONAL LAW JOURNAL 1 (2007). ${ }^{16}$ RudOlF DOLZER \& CHISTOPH SCHREUER, PRINCIPLES OF INTERNATIONAL INVESTMENT LAW, 214 (2008). 
Convention" (Article 26), but this "possibility is hardly ever used". ${ }^{17}$ Similarly, there could be a provision of a fork in the road clause. Pursuant to this provision, once the investor chooses between domestic courts or international arbitration, this choice is binding to all claims related to the alleged breach of rights.

As already said, the international investor-State arbitration is the dispute settlement provision most commonly in BIT's. International arbitration can be chosen between an arbitration institution and ad hoc arbitration. The arbitration institution provides the rules of procedure and institutional support to the arbiters of the case. Some examples of these kind of institutions are the International Centre for Settlement of Investment Disputes (ICSID), the International Chamber of Commerce (ICC), London Court of International Arbitration (LCIA), and other regional arbitration centers, like Singapore International Arbitration Centre (SIAC) and Kuala Lumpur Regional Centre for Arbitration (KLRCA).

Salacuse identifies four alternatives to international arbitration for investor-State disputes, namely:

(1) recourse to the courts or other judicial institutions of the host country; (2) acceptance of governmental action by absorbing or off-setting the costs of alleged wrongful governmental action or inaction; (3) direct negotiation of a settlement of the dispute with the host government; or (4) mediation, conciliation, or other non-binding dispute resolution methods involving the help of a third party. ${ }^{18}$

To better understand investor-State disputes, it is important to take into account that investor-State forms of dispute resolution have at least one more different character. Understanding the role of the two or more States that have signed the investment treaty is central to the dispute settlement. The investor is usually a multinational enterprise that has its head office in one State that signed a BIT with the host State. The host State has signed the BIT, or another treaty, with at least one other State. Considering this, there is at least another player in this dispute to be considered.

${ }^{17}$ RUDOLF DOLZER \& CHISTOPH SCHREUER, PRINCIPLES OF INTERNATIONAL INVESTMENT LAW, 215 (2008).

${ }^{18}$ Jeswald Salacuse, Is There a Better Way? Alternative Methods of Treaty-Based, InvestorState Dispute Resolution, 31 FORDHAM INTERNATIONAL LAW JOURNAL 1, 162 (2007). 
So the forms to settle an investor-State dispute could be: (i) negotiation between the host State and the investor's State; (ii) direct negotiation between the host State and the investor; (iii) mediation or conciliation between the host State and the investor's State; (iv) mediation or conciliation between the host State and the investor; (v) arbitration between the host State and the investor's State; (vi) arbitration between the host State and the investor; (vii) adjudication in the host State's domestic courts; (vii) adjudication in international courts between the host State and the investor's State; and (viii) direct adjudication in international courts between the investor and host State.

Another topic that has been studied by scholars is the use of alternative dispute resolution methods to investment disputes. In this sense, the alternative to state jurisdiction is ADR, while in international investor-State disputes, the alternatives are to arbitration, since this is the most common dispute provision in BITs and other forms of contracts. For example, Salacuse shows a concern towards whether there is a "better way than international arbitration to resolve at least some investor-State disputes". ${ }^{19}$ The author explains that "there are three basic areas that mediators seek to address in their efforts to facilitate a negotiated agreement between the parties: a) process, b) communications, and c) substance". ${ }^{20}$

To improve the use of mediation in international investor-State disputes, Salacuse proposes: (i) to improve the education and research about ADR applications to investor-State disputes; (ii) pro-active approach by institutions (such as ICSID and ICC) with a "multi-door approach"; (iii) policies to facilitate early interventions in conflicts; (iv) creation of an International Investment Mediation Service; (v) search for ways to associate ADR with arbitration; (vi) enact legislation authorizing host country officials to use ADR; and (vii) revise treaty language to encourage ADR in investor-State disputes. ${ }^{21}$

This article is not focused on how ADR could be used to overcome disputes between investors and the host State. The focus here is to identify the new provisions on investor-host State settlement, to think about how the investment dispute system is changing.

${ }_{19}$ Jeswald Salacuse, Is There a Better Way? Alternative Methods of Treaty-Based, InvestorState Dispute Resolution, 31 FORDHAM INTERNATIONAL LAW JOURNAL 1, 140 (2007).

${ }^{20}$ Jeswald Salacuse, Is There a Better Way? Alternative Methods of Treaty-Based, InvestorState Dispute Resolution, 31 FORDHAM INTERNATIONAL LAW JOURNAL 1, 160 (2007).

${ }^{21}$ Jeswald Salacuse, Is There a Better Way? Alternative Methods of Treaty-Based, InvestorState Dispute Resolution, 31 FORDHAM INTERNATIONAL LAW JOURNAL 1, 180-184 (2007).

3 JOURNAL OF INSTITUTIONAL STUDIES 2 (2017) 


\section{Arbitration in International Investment Dispute Settlement}

In the last years, the major conflicts about the treaties to promote foreign investment has been raised by cases judged mostly by arbitration. ${ }^{22}$ Salacuse identifies and examines six reasons for the growth of investor-State international arbitration:

(1) the growing availability of arbitration as a remedy; (2) the politics of investor-State disputes; (3) the occurrence of major crises; (4) the transformation of the global investment climate; (5) the development of facilitating factors; and [...] (6) the perceived lack of satisfactory dispute resolution alternatives to international arbitration for the settlement of investor-State disputes. ${ }^{23}$

In 1966, the World Bank created the International Centre for Settlement of Investment Disputes (ICSID). ICSID arbitration provides "the standard for other types of treaty-based arbitration". ${ }^{24}$ World Bank created it "in the belief that the provision of neutral arbitration facilities for investment disputes between foreign investors and host states will boost investor confidence in the host states which participate in the ICSID Convention". 25

According to ICSID, "as of June 30, 2016, ICSID had registered 570 cases under the ICSID Convention and Additional Facility Rules", being 510 ICSID Convention Arbitration Cases (89.5\%), 08 ICSID Convention

22 To Salacuse, "in the international investment domain, however, where international adjudication has an extremely limited scope and where arbitration under investment treaties has become a standard form of dispute resolution, the term 'alternative dispute resolution' can refer to those dispute resolution processes that stand as alternatives to both international arbitration and adjudication in domestic courts". Jeswald Salacuse, Is There a Better Way? Alternative Methods of Treaty-Based, Investor-State Dispute Resolution, 31 FORDHAM INTERNATIONAL LAW JOURNAL 1, 156 (2007).

${ }^{23}$ Jeswald Salacuse, Is There a Better Way? Alternative Methods of Treaty-Based, InvestorState Dispute Resolution, 31 FORDHAM INTERNATIONAL LAW JOURNAL 1, 148 (2007).

${ }^{24}$ MUTHUCUMARASWAMY SORNARAJAH, THE INTERNATIONAL LAW ON FOREIGN INVESTMENT, 306 (3 ${ }^{\mathrm{RD}}$ ED., 2010).

${ }^{25}$ MUTHUCUMARASWAMY SORNARAJAH, THE INTERNATIONAL LAW ON FOREIGN INVESTMENT, 65 (3RD ED., 2010). 
Conciliation Cases (1.4\%), 50 ICSID Additional Facility Arbitration Cases $(8.8 \%)$ and 2 ICSID Additional Facility Conciliation Cases (0.4\%). ${ }^{26}$ BITs are the basis to invoke ICSID arbitration in $60 \%$ of the cases, while Investment Contracts between the Investor and the Host-State are the basis of $16.9 \%$ of the cases and $9.2 \%$ is based on the Energy Charter Treaty (ECT).

In the ICSID system, investors usually initiate the claims against host States. Salacuse says that:

among the 133 concluded arbitration cases registered at the International Centre for Settlement of Investment Disputes ("ICSID") in its history, only two as of 2006 were initiated by states, and jurisdiction in both cases was based on contracts with the investor, not investment treaties. ${ }^{27}$

Sornarajah understand this as a "more important outcome" of the treaties that contains arbitration provision, since these treaties gives "multinational corporations the rights to unilaterally invoke arbitration". ${ }^{28}$ However, the main form to settle investor-State disputes is

${ }^{26}$ All data is available at

$<$ https://icsid.worldbank.org/en/Documents/resources/ICSID\%20Web\%20Stats\%202016 -2\%20(English)\%20Sept\%2020\%20-\%20corrected.pdf>, accessed on Sep. 16, 2016.

${ }^{27}$ Jeswald Salacuse, Is There a Better Way? Alternative Methods of Treaty-Based, InvestorState Dispute Resolution, 31 FORDHAM INTERNATIONAL LAW JOURNAL 1, 145 (2007).

${ }^{28}$ Muthucumaraswamy Sornarajah also states that "[...] ICSID, consistent with the neo-conservative vision of its parent body, the World Bank, promotes notions of investment protection and liberalization that accentuate free flows of assets and maximum protection of the property of multinational corporations on the untested assumption that such flows of foreign investment bring about economic development. There has been no credible evidence to show that investment treaties or arbitration promote foreign investment flows. World Bank studies, as well as other studies, show that there is no credible evidence to show a correlation between investment treaties and foreign investment flows. It is an instance when developing states are compelled to lose sovereignty". Muthucumaraswamy Sornarajah, Power and Justice: Third World Resistance in International Law, 10 SINGAPORE YEAR BOOK OF INTERNATIONAL LAW 19, 32 (2006). To Sornarajah "ICSID arbitration is a system founded upon the neoconservative tenet that foreign investment arbitration is uniformly beneficial", in the sense that since the international investment treaties will always bring development to the countries involved, there is no need to take into account or to listen to the States 
arbitration between the investor and the host State, mostly through the ICSID system.

Years later, in 1988, the World Bank also created the Multilateral Investment Guarantee Agency (MIGA) "to provide for a scheme of insurance against political risk in developing states" ${ }^{29}$ But after years of these two institutions functioning, "it is difficult to assess whether they have helped to increase the flow of investments into the developing world".30

\section{FAILURES (OR CONCERNS) OF ARBITRATION SETTLEMENT MODEL}

Lately, international investment arbitration has been a "hot topic". There are several scholars that study the failures about this settlement model. Within the current international investment arbitration system, multinational corporations have the right to investment protection within international arbitration, but have no responsibilities to be taken, since they are "entities which are supposed to be without personality in positivist international law". ${ }^{31}$ This right to access arbitration directly leads to a phenomenon that some scholars identified being similar to the "litigation explosion" occurred in the USA in the 70s, that also occurred in other countries. ${ }^{32}$ In this sense, to Papa the state dissatisfaction related

that are involved in this dispute. Just the multinational enterprise and the host State are sufficient to be in the dispute, "without gaining anything in return for doing so." Muthucumaraswamy Sornarajah, Power and Justice: Third World Resistance in International Law, 10 SINGAPORE YEAR BOOK OF INTERNATIONAL LAW 19, 32 (2006).

29 MUTHUCUMARASWAMY SORNARAJAH, THE INTERNATIONAL LAW ON FOREIGN INVESTMENT, 65 (3RD ED., 2010).

${ }^{30}$ MUTHUCUMARASWAMY SORNARAJAH, THE INTERNATIONAL LAW ON FOREIGN INVESTMENT, 66 (3RD ED., 2010).

${ }^{31}$ Muthucumaraswamy Sornarajah, Power and Justice: Third World Resistance in International Law, 10 SINGAPORE YEAR BOOK OF INTERNATIONAL LAW 19, 32 (2006).

32 "For some governments and observers, the growth in the number of treaty-based, investor-State arbitrations is a new form of 'litigation explosion', comparable to the litigation 'boom' experienced in the United States, a situation that has provoked a search for alternative dispute resolution mechanisms". Jeswald Salacuse, Is There a Better Way? Alternative Methods of Treaty-Based, Investor-State Dispute Resolution, 31 FORDHAM INTERNATIONAL LAW JOURNAL 1, 162 (2007). 
to international investment arbitration "is latent because states constrain their ability to exercise their power and serve as sovereign guardians of public interest". ${ }^{33}$

To Salacuse both arbitration and adjudication have several disadvantages. In general, both models of dispute settlement are (i) costly, (ii) time-consuming; (iii) unpredictable; (iv) lack finality in some cases; and (v) "destroy the business relationship between the disputants in nearly all cases". ${ }^{34}$ Regarding international investment arbitration specifically, scholars like Susan Franck, says the systems lacks "legitimacy, transparency, determinacy, and coherence". ${ }^{35}$

Franck is concerned about inconsistent investor-State arbitration cases. The author summarizes inconsistent cases in three different categories:

(1) cases involving the same facts, related parties, and similar investment rights, (2) cases involving similar commercial situations and similar investment rights, and (3) cases involving different parties, different commercial situations, and the same investment rights. ${ }^{36}$

According to Franck, "the options for addressing these inconsistent decisions are limited" in the current arbitration treaty system, since "there is no uniform mechanism to correct inconsistent decisions". ${ }^{37}$ The provisions to review investor-States arbitration decision "was inherited

${ }^{33}$ Mihaela Papa, BRICS and Politics of Reforming Global Governance: The Case of Investment Arbitration, in CRITICAL LEGAL PERSPECTIVES ON GLOBAL GOVERNANCE: LIBER AMICORUM DAVID M TRUBEK, 414 (Gráinne de Búrca, Claire Kilpatrick \& Joanne Scott eds., 2014).

${ }^{34}$ Jeswald Salacuse, Is There a Better Way? Alternative Methods of Treaty-Based, InvestorState Dispute Resolution, 31 FordHAM INTERNATIONAL LAW JOURNAL 1, 155 (2007).

${ }^{35}$ Susan Franck, The Legitimacy Crisis in Investment Treaty Arbitration: Privatizing Public International Law through Inconsistent Decisions, 73 FORDHAM LAW REVIEW 4, 1524 (2005), available at $<$ http://ssrn.com/abstract $=812964>$, accessed on Sep. 21, 2016.

36 Susan Franck, The Legitimacy Crisis in Investment Treaty Arbitration: Privatizing Public International Law through Inconsistent Decisions, 73 FORDHAM LAW REVIEW 4, 1588 (2005), available at $<$ http://ssrn.com/abstract $=812964>$, accessed on Sep. 21, 2016.

${ }^{37}$ Susan Franck, The Legitimacy Crisis in Investment Treaty Arbitration: Privatizing Public International Law through Inconsistent Decisions, 73 FORDHAM LAW REVIEW 4, 1546 (2005), available at $<$ http://ssrn.com/abstract $=812964>$, accessed on Sep. 21, 2016. 
from international commercial arbitration, but these neither permit review of the merits nor correction of legal errors". For example, the ICSID Washington Convention provides for the annulment of the decision in its Article 52. But the grounds for the annulment aims to address procedural deficiencies as: (1) the original arbitral tribunal was not properly constituted, (2) the arbitral tribunal manifestly exceeded its powers, (3) a tribunal member was corrupt, (4) there was a serious departure from a fundamental rule of procedure, or (5) the award does not state the reasons upon which it was based.

To Sornarajah, when it comes to international investment arbitration transparency:

what is central to the developments in this field is that a handful of the so called 'arbitration fraternity' has arrogated for itself the power to make law in this field without any democratic mandate or a basis of acceptance within the international community. 38

The question about the democratic mandate or a basis of acceptance is related to who will judge the cases and how these judges, or arbitrators, of the case will be chosen.

The United Nations Conference on Trade and Development (UNCTAD), established in 1964 as a permanent intergovernmental body, sums up the concerns about investor-State dispute settlement as follows: (i) perceived deficit of legitimacy and transparency; (ii) contradictions between arbitral awards; (iii) difficulties in correcting erroneous arbitral decisions; (iv) questions about the independence and impartiality of arbitrators, and (v) concerns relating to the costs and time of arbitral procedures. ${ }^{39}$

${ }^{38}$ Muthucumaraswamy Sornarajah continues the argument: "It is a shotgun approach to the purported making of law, with international institutions giving loans, multinational corporations and developed states acting in tandem to ensure that awards are made on the basis of norms that suit property protection". Muthucumaraswamy Sornarajah, Power and Justice: Third World Resistance in International Law, 10 SINGAPORE YEAR BOOK OF INTERNATIONAL LAW 19, 35 (2006). 39 United Nations Conference on Trade and Development (UNCTAD) Secretariat, Reform of Investor-State Dispute Settlement: in search of a roadmap, INTERNATIONAL INVESTMENT AGREEMENTS, No. 2 (June 2013), available at $<$ http://unctad.org/en/PublicationsLibrary/webdiaepcb2013d4 en.pdf $>$, accessed on Oct. 10, 2016. 
Another problem about these conflicts is also related to the lack of regulation expressed about what would be the state regulatory powers in the BITs and other agreements. This tension between the regulatory power of the host State and the foreign investor has been judged in cases like the Metalclad v. Mexico, involving a hazardous waste site; Ethyl $v$. Canada, that involved a fuel additive; Azinian v. Mexico about a municipal waste concession, Compañia de Aguas del Aconquija S.A. and Vivendi Universal S.A. $v$. The Argentine Republic, about water and sewage in the province of Tucuman, Argentine, and others. ${ }^{40}$ Most recently, the decision of the case Philip Morris Asia Ltd v. The Commonwealth of Australia is an example of this tension.

The Philip Morris v. Australia case concerned the introduction of tobacco plain packaging rules in Australia. Philip Morris claimed that this regulative alteration violated the Agreement between the Government of Hong Kong and the Government of Australia for the Promotion and Protection of Investments, dated 15 September 1993. Philip Morris claimed billions of Australian dollars for damage due to the "Tobacco Plain Packaging Act 2011" and the" Tobacco Plain Packaging Regulations 2011", which prohibited the use of brands, trademarks and logos on tobacco packaging. Philip Morris' argument considered this alteration as "an indirect expropriation of its intellectual property rights and transformed its Australian subsidiary". ${ }^{41}$

The tribunal decided it lacked jurisdiction in this case. Due to the change in Philip Morris' headquarters from Switzerland to Hong Kong resulting from a corporate restructuration, the tribunal decided for an abuse of right and the lack of jurisdiction in this case. In spite of inadmissibility decision in Philip Morris, the case is important to think about some issues related to the question of the power of public regulation. More specifically how to think about indirect expropriation (or regulatory expropriation), meaning the situation in which the State adopts a regulatory measure that can be equated to an expropriation.

Resuming the common failures appointed by scholars and

${ }^{40}$ Andrew Newcombe, The Boundaries of Regulatory Expropriation in International Law, 20 INTERNATIONAL CENTER FOR SETTLEMENT OF INVESTMENT DISPUTES REVIEW - FOREIGN INVESTMENT LAW JOURNAL 1, 1 (2005), available at $<$ http://ssrn.com/abstract=703244 $>$, accessed on Oct. 10, 2016.

${ }^{41}$ Cf. Edward Poulton \& Richard Allen, Smoke and Mirrors? Structuring of Foreign Investments Following the Philip Morris Award, GLOBAL ARBITRATION NEWS (June 8, 2016), available at $<$ http://globalarbitrationnews.com/smoke-mirrors-structuringforeign-investments-following-philip-morris-award-20160608/>, accessed on Oct. 10, 2016. 
international bodies to the international investment arbitration are: (i) the democratic issue, which considers questions on who will decide the claims and how they will be chosen; (ii) the jurisdiction issue, dealing with State regulatory sovereignty interference; (iii) lack of transparency, that concerns what has been decided and who can influence the decision (iv) coherence, annulment and appellation, regarding to decisions that do not apply correctly the law. In the next chapter, this article examines the reforms to the international investment disputes provisions and analyses three different approaches to its reforms.

\section{OVERCOMING THE FAILURES?}

UNCTAD traces five possible paths to reform ISDS: (i) to promote alternative dispute resolution; (ii) to tailor the existing system through individual international investment agreements; (iii) limiting investor access to ISDS; (iv) introducing an appeals facility; and (v) creating a standing international investment court. ${ }^{42}$

To do this, UNCTAD proposes to reform international investment agreement clauses that has three different ways to reform the ISDS mechanism. When one looks at the possible reforms related to the ISDS mechanism, it can (i) "Fix the existing ISDS mechanism by improving transparency, limiting investors' access, enhancing the contracting parties' control and introducing local litigation requirements". ${ }^{43}$ In the same perspective, the reform could (ii) "Add new elements to the existing ISDS mechanism (e.g. building in effective alternative methods of dispute resolution, introducing an appeals facility)". ${ }^{44}$ Finally, in the same

42 United Nations Conference on Trade and Development (UNCTAD) Secretariat, Reform of Investor-State Dispute Settlement: in search of a roadmap, INTERNATIONAL INVESTMENT AGREEMENTS, No. 2 (June 2013), available at $<$ http://unctad.org/en/PublicationsLibrary/webdiaepcb2013d4 en.pdf $>$, accessed on Oct. 10, 2016.

${ }^{43}$ United Nations Conference on Trade and Development (UNCTAD) Secretariat, Reform of Investor-State Dispute Settlement: in search of a roadmap, INTERNATIONAL INVESTMENT AGREEMENTS, No. 2 (June 2013), available at

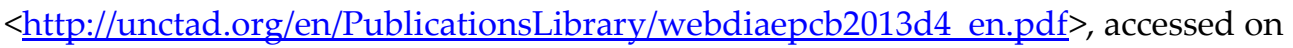
Oct. 10, 2016.

${ }^{44}$ United Nations Conference on Trade and Development (UNCTAD) Secretariat, Reform of Investor-State Dispute Settlement: in search of a roadmap, INTERNATIONAL INVESTMENT AGREEMENTS, No. 2 (June 2013), available at 
perspective, the reform could (iii) "Replace the existing ISDS mechanism (e.g. by creating a standing international investment court, reliance on State-State dispute settlement and/or reliance on domestic dispute resolution)" ${ }^{45}$

This chapter analyses three different approaches to the reform ISDS. The first one is the European approach, focusing on the CETA agreement and TTIP negotiations. The second approach is the American approach, concerning the TPP agreement. The last one is the Brazilian approach, concerning the Agreement on Cooperation and Facilitation of Investment (ACFI) that Brazil has recently signed with some Latin-American and African countries.

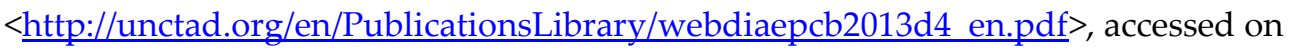
Oct. 10, 2016.

${ }^{45}$ Cf. United Nations Conference on Trade and Development (UNCTAD) Secretariat, Reform of Investor-State Dispute Settlement: in search of a roadmap, INTERNATIONAL INVESTMENT AGREEMENTS, No. 2 (June 2013), available at $<$ http://unctad.org/en/PublicationsLibrary/webdiaepcb2013d4 en.pdf $>$, accessed on Oct. 10, 2016. Susan Franck summarizes four categories, or approaches, to change international investment dispute resolution. The first one is the Legislative approach that "advocate reducing inconsistency and promoting legitimacy by providing textual certainty in investment treaties". Susan Franck, The Legitimacy Crisis in Investment Treaty Arbitration: Privatizing Public International Law through Inconsistent Decisions, 73 FORDHAM LAW REVIEW 4, 1588 (2005), available at <http://ssrn.com/abstract=812964>, accessed on Sep. 21, 2016. The second one is the "Barrier Building" Approach, that "accept arbitration as a legitimate dispute resolution mechanism, but dislike how investors use it", with emphasis in the "creation of preconditions to arbitration". Susan Franck, The Legitimacy Crisis in Investment Treaty Arbitration: Privatizing Public International Law through Inconsistent Decisions, 73 FORDHAM LAW REVIEW 4, 1589 (2005), available at $<$ http://ssrn.com/abstract $=812964>$, accessed on Sep. 21, 2016. The third is the arbitration rejection approach that rejects arbitration and presents a return to a public forum, like a permanent judicial body. Finally, the last is the "Safeguard Builders" approach that "suggest structural modifications to the arbitration mechanism to promote legitimacy". Susan Franck, The Legitimacy Crisis in Investment Treaty Arbitration: Privatizing Public International Law through Inconsistent Decisions, 73 FORDHAM LAW REVIEW 4, 1588 (2005), available at <http://ssrn.com/abstract=812964>, accessed on Sep. 21, 2016. 


\section{European approach}

\subsection{Comprehensive Economic Trade Agreement (CETA)}

Since June 2009, the European Commission and Canada have been negotiating an Economic Integration agreement that also includes a provision for investment protection and investment dispute settlement. ${ }^{46}$ In December 2015, the Council of the European Union made the negotiating mandates public. ${ }^{47}$ The parties revised the first draft, publishing the new version in February 2016. ${ }^{48}$ The draft revisions focused "on the controversial and deeply flawed process of investor-state dispute settlement (ISDS)". ${ }^{49}$ The ongoing negotiations of this "megaregional" agreement on trade and investment between Europe Union and Canada changes the investor-State disputes about foreign investment.

The chapter eight of CETA brings provisions about investment. ${ }^{50} \mathrm{It}$ defines investment and investment provisions' scope, excluding Financial Services from the investment definition, since Financial Services are provided in Chapter 15. The eighth chapter also provides regulation

${ }^{46}$ According to European Commission, "CETA includes an investment protection and dispute settlement system which matches the expectations of the EU's and Canada's citizens and businesses. The new system is fairer and more transparent and has a solid institutional framework. At the same time, it will continue to resolve investment disputes quickly". Available at <http://ec.europa.eu/trade/policy/in-focus/ceta/>, accessed on Oct. 10, 2016.

${ }^{47}$ The document is available at $<$ http://data.consilium.europa.eu/doc/document/ST9036-2009-EXT-2/en/pdf $>$, accessed on Oct. 18, 2016.

${ }_{48}$ In July 2016, the European Commission proposed the signature of the CETA to the Council of the EU. If the Council of the EU approves the agreement, the European Parliament has to consent to the agreement be signed. The revised draft is available at $<$ http://trade.ec.europa.eu/doclib/docs/2016/february/tradoc 154329.pdf $>$, accessed on Oct. 18, 2016.

${ }^{49}$ Gus Van Harten, ISDS in the Revised CETA: Positive Steps, But Is It the "Gold Standard"?, INVESTOR-STATE ARBITRATION COMMENTARY SERIES, No. 6 (2016), available at $<$ https://www.cigionline.org/publications/isds-revised-ceta-positive-steps-it-goldstandard $>$, accessed on Oct. 18, 2016.

${ }^{50}$ Also CETA's preamble recognizes "that the provisions of this Agreement protect investments and investors with respect to their investments, and are intended to stimulate mutually-beneficial business activity, without undermining the right of the Parties to regulate in the public interest within their territories". 
about market access, performance requirements, non-discriminatory treatment and investment protection. Within the investment protection, the chapter's clauses provide investment and regulatory measures, treatment of investors and covered investments, compensation for losses, expropriation, transfers and subrogation.

Regarding investor-State dispute settlement, CETA creates a Tribunal with the ICSID institution support (article 8.23, CETA). This Tribunal has 15 members at the beginning ( 5 from Canada, 5 from Europe Union and 5 from third parties). In this sense, it guarantees "more public accountability in their initial appointment and they will be assigned to cases in an objective way". ${ }^{51}$ Each Arbitral Tribunal division will be composed by one national of a Member State of the EU, one national of Canada and one national of a third country. The chairperson of the Tribunal shall be the national of a third country (article 8.27, §6, CETA).

The critics about the Tribunal are: (i) ISDS adjudicators can "work on the side as ISDS arbitrators"; and (ii) "CETA's language on the expertise of ISDS adjudicators, suggests a way has been cleared for the same clubby crowd of investor-friendly arbitrators to dominate ISDS under CETA". 52

Transparency of proceedings are also object of CETA. It determines that the UNCITRAL Transparency Rules shall apply with the modifications of article 8.36, CETA. The non-disputing Party shall request or be invited to provide oral or written submissions from the nondisputing Party regarding the interpretation of the Agreement (Article 8.38, CETA).

CETA also creates an Appellate Tribunal to review awards regarding investments disputes (article 8.28, CETA). It also pursues the "Establishment of a multilateral investment tribunal and appellate mechanism" (article 8.29, CETA). The resolution of investment disputes between investors and states do not prejudice rights and obligations about the Dispute Settlement provided in Chapter Twenty-Nine, regarding consultations between the States, mediation and arbitration to resolve any dispute concerning the interpretation or application of the CETA's provisions.

${ }^{51}$ Gus Van Harten, ISDS in the Revised CETA: Positive Steps, But Is It the "Gold

Standard"?, INVESTOR-STATE ARBITRATION COMMENTARY SERIES, No. 6 (2016), available at $<$ https://www.cigionline.org/publications/isds-revised-ceta-positive-steps-it-goldstandard>, accessed on Oct. 18, 2016.

${ }^{52}$ Gus Van Harten, ISDS in the Revised CETA: Positive Steps, But Is It the "Gold Standard"?, INVESTOR-STATE ARBITRATION COMMENTARY SERIES, No. 6 (2016), available at $<$ https://www.cigionline.org/publications/isds-revised-ceta-positive-steps-it-goldstandard $>$, accessed on Oct. 18, 2016.

3 JOURNAL OF INSTITUTIONAL STUDIES 2 (2017) 
More recently, the German Federal Constitutional $\operatorname{Court}^{53}$ rejected several applications for a preliminary injunction directed against the approval by the German representative in the Council of the European Union of the signing, the concluding and the provisional application of CETA, which the Council of the European Union was expected to decide upon on 18 October 2016.

This decision brings an important consideration about the investment chapter and the investor-State dispute resolution system CETA creates. In its decision, the German Federal Constitutional Court stressed that "the Federal Government has made it clear that it will only lend approval in the Council to those parts of CETA that lie beyond doubt within the competences attributed to the European Union under primary law". ${ }^{54}$ This happens because the German Federal Government submission states that "it will not approve the provisional application for areas that remain subject to the competence of the Federal Republic of Germany."

According to the Bundesverfassungsgerichts, "the provisions on investment protection, including the dispute settlement system (Chapters 8 and 13 CETA)" do not fall under the exclusive competence of the EU, and these provisions have to be ratified in Germany (and all other EU Member States).

Even though CETA's provisions about investment protection and the dispute settlement system shall be ratified by every EU member state, it is important to stress that CETA adds new elements to the existing ISDS mechanism. The creation of a Tribunal based on ISCID and an appellate tribunal, as well as mechanisms of transparency, adopting the UNCITRAL rules on transparency, are a turning point in ISDS.

\subsection{Transatlantic Trade and Investment Partnership (TTIP): the International Investment Court}

The Transatlantic Trade and Investment Partnership (TTIP) is a trade and

${ }^{53}$ Federal Constitutional Court, Applications for a Preliminary Injunction in the "CETA" Proceedings Unsuccessful, PRESS RELEASE, No. 71/2016 (Oct. 13, 2016), available at $<$ http://www.bundesverfassungsgericht.de/SharedDocs/Pressemitteilungen/EN/2016/b vg16-071.html >, accessed on Oct. 20, 2016.

${ }^{54}$ Federal Constitutional Court, Applications for a Preliminary Injunction in the "CETA" Proceedings Unsuccessful, PRESS RELEASE, No. 71/2016 (Oct. 13, 2016), available at $<$ http://www.bundesverfassungsgericht.de/SharedDocs/Pressemitteilungen/EN/2016/b vg16-071.html $>$, accessed on Oct. 20, 2016. 
investment agreement currently under negotiation between the United States and the European Union. The TTIP agreement has been a topic of intense controversy. ${ }^{55}$ This section aims to analyze the EU's position in the negotiations regarding the ISDS, according to the European Commission's draft text of TTIP..$^{56}$

In the document that EU Commission explains the TTIP chapter by chapter, it claims that:

many investment agreements that EU countries already have in place don't strike the right balance that the EU wants to see between: guaranteeing governments' right to regulate; and the need to protect investors. So the system, including ISDS, needs improving and updating. ${ }^{57}$

The EU Commission wants to (i) review "the way ISDS tribunals work and how we appoint the arbitrators that sit on them"; (ii) create "a system that allows either side in a case to appeal against a tribunal's decision"; and (iii) strengthen "EU governments' right to regulate in the public

${ }^{55}$ Julia Kollewe, What is TTIP? The controversial trade deal proposal explained, THE GUARDIAN (Jul. 3, 2015), available at

$<$ https://www.theguardian.com/business/2015/jul/03/what-is-ttip-controversial-tradedeal-explained>, accessed on Oct. 18, 2016; and Andrew Walker, TTIP: Why the EU-US trade deal matters, BBC News (May 13, 2015), available at $<$ http://www.bbc.com/news/business-32691589>, accessed on Oct. 18, 2016.

56 Transatlantic Trade and Investment Partnership. Trade in services, investment and ecommerce. Chapter II - Investment. The document is available at $<$ http://trade.ec.europa.eu/doclib/docs/2015/september/tradoc 153807.pdf $>$, accessed on Oct. 18, 2016. According to the EU Commission this document "is not a formal text proposal to the United States in the TTIP negotiations but an internal document of the European Union. The Commission will consult the EU's Member States in the Council and will discuss the proposal with the European Parliament before presenting a formal text proposal to the United States". Available at $<$ http://europa.eu/rapid/pressrelease MEMO-15-5652 en.htm $>$, accessed on Oct. 18, 2016.

57 EUROPEAN COMMISSION, THE TRANSATLANTIC TRADE AND INVESTMENT PARTNERSHIP (TTIP): TOWARDS AN EU-US TRADE DEAL, 41 (2015), available at $<$ http://trade.ec.europa.eu/doclib/docs/2015/july/tradoc 153635.pdf $>$, accessed on Oct. $18,2016$. 
interest". ${ }^{58}$

Aiming such improvement, similarly to the CETA's proposals, the EU Commission's TTIP draft in its Chapter 2, Section 3, provides the Resolution of Investment Disputes and Investment Court System. The subsection one provides the definitions and scope of the investment court system, while subsections 2, 3 and 4 provide the amicable resolution, mediation and consultation, respectively.

The European Commission's draft proposes the creation of a TTIP Committee to act as "an inter-governmental body through which the TTIP parties can issue authoritative interpretations of TTIP". The EU Commission proposes to create a Tribunal of First Instance (article 9, TTIP) and an Appellate Tribunal (article 10, TTIP).

The First Instance Tribunal will have at least fifteen judges, five from nationals of European Union, five shall be nationals of the United States and five shall be nationals of third countries. The judges shall have expertise in public international law and expertise in international investment law, international trade law and the resolution of disputes arising under international investment or international trade agreements. ${ }^{59}$

The Appellate Tribunal will have six members, two from the EU, two from US and two from third parties. Each treaty Party shall propose three candidates, two of which may be nationals of that Party and one shall be a non-national, for the TTIP Committee to thereafter jointly appoint the Appellate Tribunal Members (article 10, n. 3, TTIP). Judges will be paid a monthly retainer fee (proposed as $€ 2,000$ per month for judges at the Tribunal of First Instance and $€ 7,000$ per month for judges at the appellate level).

The EU Commission draft also provides the transparency model, adopting the UNCITRAL Transparency Rules, which are applied with some modifications (article 18, TTIP). There is the provision of

${ }^{58}$ EUROPEAN COMMISSION, THE TRANSATLANTIC TRADE AND INVESTMENT PARTNERSHIP (TTIP): TOWARDS AN EU-US TRADE DEAL, 41-42 (2015), available at $<$ http://trade.ec.europa.eu/doclib/docs/2015/july/tradoc 153635.pdf $>$, accessed on Oct. 18, 2016.

59 "The Judges shall possess the qualifications required in their respective countries for appointment to judicial office, or be jurists of recognised competence. They shall have demonstrated expertise in public international law. It is desirable that they have expertise in particular, in international investment law, international trade law and the resolution of disputes arising under international investment or international trade agreements." 
intervention by third parties (Article 23, TTIP).

Thereby, the EU TTIP proposal replaces the existing ISDS mechanism, because it creates a TTIP international investment court and an Investment Appellate Tribunal. According to Barnali Choudhury, the EU proposal to create a TTIP Investment Tribunal "overhauls the current system of investor-state dispute settlement" ${ }^{60}$

\section{USA approach: the Trans-Pacific Partnership (TPP) Agreement}

The Trans-Pacific Partnership (TPP) is a trade and investment agreement between United States, Australia, Canada, Japan, Malaysia, Mexico, Peru, Vietnam, Chile, Brunei, Singapore and New Zealand. ${ }^{61}$ To the U.S., one of the main TTP objectives is to exercise its global leadership within:

The rules of the road are up for grabs in Asia. If we [U.S.] don't pass this agreement and write those rules, competitors will set weak rules of the road, threatening American jobs and workers while undermining U.S. leadership in Asia. ${ }^{62}$

Concerning the ISDS system, the U.S. declares that "TPP also serves to modernize and reform ISDS by including clearer language and stronger safeguards that raise standards above virtually all of the other 3,000 plus investment agreements in force today." 63

The TPP's Section B provides for means of Investor-State Dispute Settlement. Before starting arbitration, the investor or State should start the "consultation and negotiation, which may include the use of non-

${ }^{60}$ Barnali Choudhury, 2015: The Year of Reorienting International Investment Law, 20 American Society of International Law Insights 3 (2016), available at $<$ https://www.asil.org/insights/volume/20/issue/3/2015-year-reorienting-internationalinvestment-law $>$, accessed on Oct. 18, 2016.

${ }^{61}$ The agreement was signed in $04 / 02 / 2016$ but not yet ratified. The agreement's investment chapter is available at $<$ http://investmentpolicyhub.unctad.org/Download/TreatyFile/3573 $>$, accessed on Oct. $18,2016$.

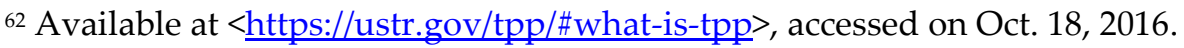

${ }^{63}$ Available at $<$ https://ustr.gov/tpp/\#upgrading-isds $>$, accessed on Oct. 18, 2016. 
binding, third party procedures, such as good offices, conciliation or mediation" (Article 9.18.1, TPP). Only six months after the receipt of the written request for consultations, a party can submit a claim to arbitration. ${ }^{64}$ Regarding the selection of the arbitrators, TPP provides that "the tribunal shall comprise three arbitrators, one arbitrator appointed by each of the disputing parties and the third, who shall be the presiding arbitrator, appointed by agreement of the disputing parties".

The TPP investment arbitration claim can be submitted under: (i) the ICSID Convention and the ICSID Rules of Procedure for Arbitration Proceedings, provided that both the respondent and the State of which the claimant is a national are parties to the ICSID Convention; (ii) the ICSID Additional Facility Rules, provided that either the respondent or the Party of the claimant is a party to the ICSID Convention; (iii) the UNCITRAL Arbitration Rules; or (iv) any other arbitral institution or any other arbitration rules, if the claimant and respondent agree.

Regarding the transparency, TPP requires ISDS panels to "conduct hearings open to the public" and to make public all notices of arbitration, pleadings, submissions, and awards. TPP provides public participation by allowing members of the public and public interest groups that have "significant interest in the arbitral proceedings" to make amicus curiae submissions to ISDS panels "regarding a matter of fact or law within the scope of the dispute" (Article 9.23.3, TPP).

The remedies under TPP agreement are set in a manner that a government can only be required to pay monetary damages, not requiring countries to change any law or regulation. Regarding the challenge of awards, TPP provides that all ISDS awards are subject to subsequent review either by domestic courts or international review panels. Related to expedited review and dismissal of claims, TPP allows panels to review and dismiss certain unmeritorious claims on an expedited basis.

Binding interpretations ISDS provisions can be agreed by the countries, since TPP provides that countries can agree on authoritative interpretations that "shall be binding on a tribunal." A TPP provision allow a panel to consolidate different claims that "arise out of the same events or circumstances", to avoid harassment through duplicative

${ }^{64}$ Annex 9-J provides that "if an investor of a Party elects to submit a claim of the type described in paragraph 1 to a court or administrative tribunal of Chile, Mexico, Peru or Viet Nam, that election shall be definitive and exclusive, and the investor may not thereafter submit the claim to arbitration under Section B (Investor-State Dispute Settlement)." 
litigation.

As it is clear from these provisions, the TTP aims to fix the existing ISDS mechanism. It does it by improving transparency, limiting investors' access, enhancing the contracting parties' control and introducing litigation requirements to the arbitration claim.

\section{Brazilian approach: agreements on cooperation and facilitation of investments}

Brazil has an interesting approach to investment treaties. It has not signed the ICSID Convention. Even though in the 1990's Brazil has signed 14 bilateral agreements with different countries, it has not ratified any of these BITs. Recently, Brazilian government has changed the policy toward bilateral treaties concerning investment. Although this Brazilian approach cannot be widely common with the called BRICS ${ }^{65}$ economies, this kind of south-south approach is important to understand the south economies (or the called developing countries) concerns and how these economies can design a ISDS mechanism different than the hegemony model.

In 2013, the Brazilian Chamber of Foreign Trade (CAMEX) approved a new template for investment agreement. This template was written by a Technical Group for Strategic Studies on Foreign Trade (GTEX), considering Brazilian needs and concerns in the international investment

\footnotetext{
${ }^{65}$ An interesting analysis about Brazil, Russia, China, India and South Africa about the international investment law in an international and country level: "The analysis of emerging powers' coalitional and country-specific behavior finds that BRICS countries are unlikely to exert joint leadership as a change-seeking coalition. At the coalitional level, investment has not yet emerged as one of the central themes in BRICS cooperation. At the country level, policies toward investment arbitration vary significantly. Some BRICS countries have already assumed major powers' trajectories in the field of investment arbitration. Other BRICS countries that were reluctant to embrace investment arbitration are rethinking their policies in light of their recent experiences as respondents to claims and increasing interest in protecting domestic investors as they engage abroad". Mihaela Papa, BRICS and Politics of Reforming Global Governance: The Case of Investment Arbitration, in CRITICAL LEGAL PERSPECTIVES ON GLOBAL GOVERNANCE: LiBER AMICORUM DAVID M TRUBEK, 407 (Gráinne de Búrca, Claire Kilpatrick \& Joanne Scott eds., 2014). More recently, Brazil and India had signed an Agreement.
} 
scenario. ${ }^{66}$ Just in 2015, Brazil has signed bilateral Agreements on Cooperation and Facilitation of Investments (ACFI) with: Mozambique ${ }^{67}$, Angola ${ }^{68}$, Mexico ${ }^{69}$, Malawi ${ }^{70}$, Colombia ${ }^{71}$ and Chile ${ }^{72}$. In 2016, Brazil has signed with Peru ${ }^{73}$ an Economic and Trade Expansion Agreement (ETEA) covering the areas of public procurement, services, investment and free trade. This Brazil-Peru agreement also provides a chapter with Investment Provisions similar to the ACFI.

The Brazilian template focus in two different topics: investment facilitation and risk mitigation. Morosoni and Badin says that, despite

${ }^{66}$ Fabio Morosini \& Michelle Badin, The Brazilian Agreement on Cooperation and Facilitation of Investment (ACFI): a New Formula for International Investment Agreement?, INVESTMENT TREATY NEWS, (Aug. 4, 2015), available at $<$ https://www.iisd.org/itn/2015/08/04/the-brazilian-agreement-on-cooperation-andfacilitation-of-investments-acfi-a-new-formula-for-international-investmentagreements/>, accessed on Oct. 18, 2016.

${ }^{67}$ The Brazil-Mozambique ACFI was signed in 30/03/2015. The text is available in

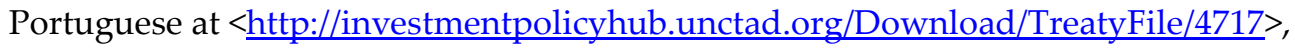
accessed on Oct. 18, 2016.

68 The Brazil-Angola ACFI was signed in 01/04/2015. The text is available in Portuguese at $\langle$ http://investmentpolicyhub.unctad.org/Download/TreatyFile/4720 $>$, accessed on Oct. 18, 2016.

${ }^{69}$ The Brazil-Mexico ACFI was signed in 26/05/2015. The text is available in Portuguese at $<$ http://investmentpolicyhub.unctad.org/Download/TreatyFile/4719 $>$, accessed on Oct. 18, 2016; and in Spanish at $<$ http://investmentpolicyhub.unctad.org/Download/TreatyFile/4718 $>$, accessed on Oct. $18,2016$.

${ }^{70}$ The Brazil-Malawi ACFI was signed in 25/06/2015. The text is available in English at $<$ http://investmentpolicyhub.unctad.org/Download/TreatyFile/4715 $>$, accessed on Oct. 18, 2016; and in Portuguese at

$<\underline{\text { http://investmentpolicyhub.unctad.org/Download/TreatyFile/4716 }}>$, accessed on Oct. $18,2016$.

${ }^{71}$ The Brazil-Colombia ACFI was signed in 09/10/2015. The text is available in

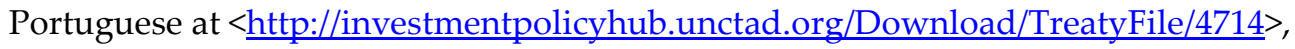
accessed on Oct. 18, 2016.

72 The Brazil-Chile ACFI was signed in 24/11/2015. The text is available in Portuguese at $<$ http://investmentpolicyhub.unctad.org/Download/TreatyFile/4713 $>$, accessed on Oct. 18, 2016.

${ }^{73}$ The Brazil-Peru ETEA was signed in 29/04/2016. The text is available in Portuguese at $<$ http://investmentpolicyhub.unctad.org/Download/TreatyFile/5324 $>$, accessed on Oct. 18, 2016. 
these two focuses are not new in the investment regime, it is "an alternative to the current international investment regime".$^{74}$ This is because the template focuses in "Constant cooperation among governmental agencies, mediated by diplomatic action, and deference to domestic legislation". In this sense, "ACFI model aims at advancing symmetry beyond formal rules, and its design takes into account the domestic needs of both capital importing and exporting countries". ${ }^{75}$

ACFI provides two different institutions: The Joint Committee and the Focal Points. While the Joint Committee works in the state-state level "as a dialogue coordinator to prevent disputes", the Focal Points has the function to provide "constant cooperation among governmental agencies, mediated by diplomatic action, and deference to domestic legislation". ${ }^{76}$

Both the Joint Committee and Focal Points will act in coordination with each other preventing disputes. These two institutions have the role to provide a "dispute settlement mechanism, based on consultations, negotiations and mediation". Whenever any dispute arises between the parties, it will be "assessed through consultations and negotiations between the Parties and previously examined by the Joint Committee". Only if these measures are not enough, arbitration can be initiated by the States. This is a fundamental difference between the other approaches, since the investor has not the power to initiate an arbitration against the host State, the arbitration is between the States involved.

In a certain way, the new Brazilian ACFI aims to replace the existing ISDS mechanism. Actually, since Brazil has never been part of the ISDS mechanism, this approach adopts another strategy in the investor-State

\footnotetext{
${ }^{74}$ Fabio Morosini \& Michelle Badin, The Brazilian Agreement on Cooperation and Facilitation of Investment (ACFI): a New Formula for International Investment Agreement?, INVESTMENT TREATY NEWS, (Aug. 4, 2015), available at $<$ https://www.iisd.org/itn/2015/08/04/the-brazilian-agreement-on-cooperation-andfacilitation-of-investments-acfi-a-new-formula-for-international-investmentagreements/>, accessed on Oct. 18, 2016.

${ }^{75}$ Fabio Morosini \& Michelle Badin, The Brazilian Agreement on Cooperation and Facilitation of Investment (ACFI): a New Formula for International Investment Agreement?, INVESTMENT TREATY NEWS, (Aug. 4, 2015), available at $<$ https://www.iisd.org/itn/2015/08/04/the-brazilian-agreement-on-cooperation-andfacilitation-of-investments-acfi-a-new-formula-for-international-investmentagreements/>, accessed on Oct. 18, 2016.

${ }^{76}$ Nitish Monebhurrun, Novelty in International Investment Law: The Brazilian Agreement on Cooperation and Facilitation of Investments as a Different International Investment Agreement Model, 8 Journal OF INTERNATIONAL Dispute SETTLEMENT 1, 6 (2017).
} 
dispute settlement, focusing in new institutions to mitigate the investments risks and foster alternative dispute resolution between the parties involved, while it adopts State-State dispute settlement.

\section{ONE STEP BACK: UNDERSTAND THE CHALLENGES TO OVERCOME THEM}

Cédric Dupont and Thomas Schultz published an article analyzing investment disputes as a political system in "a dynamic, constantly evolving system, driven by its four main actors, each of which reacting to the results of the others' input into the system". ${ }^{77}$ To Dupont and Schultz, the four main actors in this system are the states, the investors, the arbitrators and arbitration institutions. ${ }^{78}$ For these authors, the metaphor to see the international arbitration as a political system helps "to form an additional understanding that is particularly expressive of the actions and interactions of the various actors of investment arbitration, their uses of it and their adaptations to it"..$^{79}$ This metaphor also considers indirect actors, like NGOs that foster community interests or human rights, for example, but that does not participate directly in the dispute.

The states play the most important role, and this role can be identified with "their treaty-making activity, their contractual practices with foreign investors, and their domestic legislative actions", their "behaviour during

77 Cédric Dupont \& Thomas Schultz, Towards a New Heuristic Model: Investment Arbitration as a Political System, 7 JOURNAL OF INTERNATIONAL DisPUTE SETTLEMENT 1, 29 (2016)

${ }^{78}$ Cf. Cédric Dupont \& Thomas Schultz, Towards a New Heuristic Model: Investment Arbitration as a Political System, 7 JOURNAL OF INTERNATIONAL DISPUTE SETTLEMENT 1 (2016). Muthucumaraswamy Sornarajah classifies differently the actors involved in investment law: multinational corporations, State corporations, international institutions (like the World Bank the International Monetary Fund, the OECD, and the United Nations Commission on Trade and Development - UNCTAD), nongovernmental organizations (mostly to promote the environment and human rights), sovereign wealth funds and other actors like the International Chamber of Commerce. Muthucumaraswamy Sornarajah, Power and Justice: Third World Resistance in International Law, 10 SINGAPORE YEAR BOOK OF INTERNATIONAL LAW 19, 60-68 (2006).

${ }^{79}$ Cf. Cédric Dupont \& Thomas Schultz, Towards a New Heuristic Model: Investment Arbitration as a Political System, 7 JOURNAL OF INTERNATIONAL DiSPUTE SETTLEMENT 1, 5 (2016). 
arbitration procedures" and in "choosing arbitrators for institutional lists". 80

The nongovernmental organizations developed recently an important role in the international investment law. To Sornarajah, "NGOs ensure that the social dimension is kept in the forefront of issues", since "the construction of such a law on purely economic models without consideration of the social and political dimensions is not possible" ${ }^{\prime 81}$

Until now, it was possible to identify a hegemony system to the ISDS. In this hegemonic system, as analyzed in the first chapter, the role of the States was to sign mostly bilateral agreements providing arbitration to be the dispute settlement between an investor directly and the host State, without any type of interference of the home State.

The American approach, as set by the TPP, continues with these provisions contained in the hegemonic system of international investment dispute resolution. Despite proposing what United States called as an improvement of the dispute settlement system, the TPP system continues with the same assumptions that the current dispute resolution system through arbitration, mostly in ICSID, is the best system to resolve disputes between foreign investors and the home state.

But as we saw in the item IV, both the European and Brazilian approaches to the investor-State dispute settlement aims to change the role of these players. As the European way, the creation of a Tribunal and an Appellate Tribunal changes the role of the parties in choosing the arbitrators. Instead of being chosen by the investor and the disputing State, the arbitrators are sorted in a list of arbitrator, which is composed by nationals from the agreement parties and third countries. The State can be in the dispute even if it is not a disputing Party. These are important differences, since the interpretation of the agreement also affects the non-disputing Party in a system designed as a sort of Tribunal.

On the other hand, the Brazilian Approach changes the role of the investment dispute settlement players in the sense it creates two different institutions to mitigate the risks and to avoid the disputes between the investor and the host State, while it adopts only State-State arbitration to resolve the disputes that could not be amicably resolved.

This is important when we think about the challenges that the ISDS must overcome. As we saw in the previous chapters, the concerns about

${ }^{80}$ Cf. Cédric Dupont \& Thomas Schultz, Towards a New Heuristic Model: Investment Arbitration as a Political System, 7 JOURNAL OF INTERNATIONAL DisPute SETTLEMENT 1, 7 (2016).

${ }^{81}$ Muthucumaraswamy Sornarajah, Power and Justice: Third World Resistance in International Law, 10 SINGAPORE YEAR BOOK OF INTERNATIONAL LAW 19, 60-68 (2006).

3 JOURNAL OF INSTITUTIONAL STUDIES 2 (2017) 
the ISDS are different in each country. These differences are related to several factors, as the political view about foreign investment, questions about sovereignty, concerns about different national judicial bodies, concerns about the arbitration about public issues, arbitration transparency, and others. To overcome the failures of the investor-State dispute settlement is important first to understand what these failures are.

\section{CONCLUSION}

There is no one-size-fits-all investment dispute mechanism. As seen in this article, there is no consensus on what are the deficiencies of the current system for resolving disputes between international investors and states. But we can see that the reforms related to the ISDS are significant and go to different directions. This article put three different approaches on how the reforms are being discussed in treaties that have different actors as protagonists.

As noted, the US approach, as seen in the TPP with an American hegemony, is that the current ISDS has some flaws, but should be kept with some improvements. But the so-called European and Brazilian approaches give different answers to which path to take. The European approach, associated to North-North investment treaties, creates a kind of international court system, first related to the ISCID model, and then as an investment tribunal and appellate mechanism. The Brazilian approach, characterized by South-South investment treaties, creates two different institutions (Joint Committee and Focal Points) based on consultations, negotiations and mediation, and provides a State-State arbitration.

In this sense, given that none of the treaties that were seen in this article were in fact ratified by countries, it is necessary to see how the reforms will be implemented. In addition, treaties as the TTIP are still under discussion and it is necessary to see how these negotiations will continue going forward.

\section{REFERENCES}

Andrew Newcombe, The Boundaries of Regulatory Expropriation in International Law, 20 INTERNATIONAL CENTER FOR SETTLEMENT OF INVESTMENT DISPUTES REVIEW - FOREIGN INVESTMENT LAW JOURNAL 1 
(2005), available at $<\underline{\text { http: } / / \text { ssrn.com/abstract }=703244}>$, accessed on Oct. 10, 2016.

Andrew Walker, TTIP: Why the EU-US trade deal matters, BBC News (May 13, 2015), available at $<\underline{\text { http://www.bbc.com/news/business- }}$ 32691589>, accessed on Oct. 18, 2016.

Barnali Choudhury, 2015: The Year of Reorienting International Investment Law, 20 AMERICAN SOCIETY OF INTERNATIONAL LAW INSIGHTS 3 (2016), available at $<$ https://www.asil.org/insights/volume/20/issue/3/2015-yearreorienting-international-investment-law $>$, accessed on Oct. 18, 2016.

Cédric Dupont \& Thomas Schultz, Towards a New Heuristic Model: Investment Arbitration as a Political System, 7 JOURNAL OF INTERNATIONAL Dispute SetTLEMENT 1 (2016).

Christoph Schreuer, Investment, International Protection, in MAX PLANCK ENCYCLOPEDIA OF PUBLIC INTERNATIONAL LAW (Rudiger Wolfrum ed., 2013).

Edward Poulton \& Richard Allen, Smoke and Mirrors? Structuring of Foreign Investments Following the Philip Morris Award, GLOBAL ARBITRATION NEWS (June 8, 2016), available at $<$ http://globalarbitrationnews.com/smoke-mirrors-structuring-foreigninvestments-following-philip-morris-award-20160608/>, accessed on Oct. 10, 2016.

EUROPEAN COMMISSION, THE TRANSATLANTIC TRADE AND INVESTMENT PARTNERSHIP (TTIP): TOWARDS AN EU-US TRADE DEAL (2015), available at $<$ http://trade.ec.europa.eu/doclib/docs/2015/july/tradoc 153635.pdf>, accessed on Oct. 18, 2016.

Fabio Morosini \& Michelle Badin, The Brazilian Agreement on Cooperation and Facilitation of Investment (ACFI): a New Formula for International 
Investment Agreement?, INVESTMENT TREATY NeWS, (Aug. 4, 2015), available at $<$ https://www.iisd.org/itn/2015/08/04/the-brazilianagreement-on-cooperation-and-facilitation-of-investments-acfi-a-newformula-for-international-investment-agreements/>, accessed on Oct. 18, 2016.

Federal Constitutional Court, Applications for a Preliminary Injunction in the "CETA" Proceedings Unsuccessful, Press Release, No. 71/2016 (Oct. 13, 2016), available at $<$ http://www.bundesverfassungsgericht.de/SharedDocs/Pressemitteilun gen/EN/2016/bvg16-071.html>, accessed on Oct. 20, 2016.

Gus Van Harten, The Public-Private Distinction in the International Arbitration of Individual Claims against the State, 56 INTERNATIONAL AND COMPARATIVE CORPORATE LAW QUARTERLY 2 (2007).

Gus Van Harten, ISDS in the Revised CETA: Positive Steps, But Is It the "Gold Standard"?, INVESTOR-STATE ARBITRATION COMMENTARy SERIES, No. 6 (2016), available at $<$ https://www.cigionline.org/publications/isdsrevised-ceta-positive-steps-it-gold-standard>, accessed on Oct. 18, 2016.

Jeswald Salacuse, Is There a Better Way? Alternative Methods of TreatyBased, Investor-State Dispute Resolution, 31 FORDHAM INTERNATIONAL LAW JOURNAL 1 (2007).

Julia Kollewe, What is TTIP? The controversial trade deal proposal explained, THE GuARDIAN (Jul. 3, 2015), available at $<$ https://www.theguardian.com/business/2015/jul/03/what-is-ttipcontroversial-trade-deal-explained $>$, accessed on Oct. 18, 2016.

Mihaela Papa, BRICS and Politics of Reforming Global Governance: The Case of Investment Arbitration, in CRITICAL Legal PeRSPECTIVES ON GLOBAL GOVERNANCE: LIBER AMICORUM DAVID M TRUBEK, 414 (Gráinne de Búrca, Claire Kilpatrick \& Joanne Scott eds., 2014). 
Muthucumaraswamy Sornarajah, Power and Justice: Third World Resistance in International Law, 10 SINGAPORE YEAR BOOK OF INTERNATIONAL LAW 19 (2006).

MUTHUCUMARASWAMY SORNARAJAH, THE INTERNATIONAL LAW ON FOREIGN INVESTMENT (3 ${ }^{\mathrm{RD}}$ ED., 2010).

Nitish Monebhurrun, Novelty in International Investment Law: The Brazilian Agreement on Cooperation and Facilitation of Investments as a Different International Investment Agreement Model, 8 JouRnAL OF INTERNATIONAL DISPUTE SETTLEMENT 1 (2017).

RUdOLF DOLZER \& CHISTOPH SCHREUER, PRINCIPLES OF INTERNATIONAL INVESTMENT LAW (2008).

Susan Franck, The Legitimacy Crisis in Investment Treaty Arbitration: Privatizing Public International Law through Inconsistent Decisions, 73 FORDHAM LAW REVIEW 4 (2005), available at $<$ http://ssrn.com/abstract=812964>, accessed on Sep. 21, 2016.

United Nations Conference on Trade and Development (UNCTAD) Secretariat, Reform of Investor-State Dispute Settlement: in search of a roadmap, INTERNATIONAL INVESTMENT AgREEMENTS, No. 2 (June 2013), available at $<$ http://unctad.org/en/PublicationsLibrary/webdiaepcb2013d4 en.pdf $>$, accessed on Oct. 10, 2016.

Changing institutional arrangements of international investment dispute resolution in a global order: three different approaches

Mudando arranjos institucionais da resolução de disputas em investimentos internacionais em uma ordem global: três diferentes abordagens

Submitted: 2017-01-09

Accepted: 2017-11-01 